\title{
DNA Replication Licensing Factor MCM5
}

National Cancer Institute

\section{Source}

National Cancer Institute. DNA Replication Licensing Factor MCM5. NCI Thesaurus. Code C33910.

DNA replication licensing factor MCM5 (734 aa, $~ 82 \mathrm{kDa}$ ) is encoded by the human MCM5 gene. This protein plays a role in DNA replication. 